\section{Not just in California . . .}

\section{Washington}

THE biggest earthquake of historical record in the United States occurred not on the West Coast but near the town of New Madrid, Missouri, about 200 miles north of Memphis, Tennessee.

During a period of seven weeks in 181112, three earthquakes, each of estimated magnitude greater than 8 on the Richter scale, altered the course of the Mississippi River, and were felt in Chicago and Washington. Although no very large earthquakes have hit the American midwest since that time, one of the political aftershocks of the recent Loma Prieta earthquake in California (see Nature 341, 676; 1989) has been an effusion of public concern over the dangers of earthquakes throughout the country. In order not to be accused of geographical chauvinism, Congress held a hearing last week to discuss the activity of the New Madrid fault zone, and the readiness of local authorities to cope with a catastrophe.

Unlike the geological instability of the west coast, which occurs at the boundary of different tectonic plates, faulting in the New Madrid region is caused by a midplate rift. As in the Mid-Atlantic and Red Sea rifts, subterranean material wells up as lateral forces pull the plate apart, but the New Madrid fault, according to Dallas Peck, director of the US Geological Survey, is now virtually static. The faults the system complex and unpredictable. existing buildings. ville".

are buried beneath alluvial deposits carried down by the Mississippi, making

Empirically, faults between magnitudes 6 and 7 are estimated to occur about every 90 years. As recent events in California and Armenia have demonstrated, the difference between disruption and disaster from earthquakes of this magnitude has much more to do with building codes and education than geology (see Nature 337, $107 ; 1989$ ). Arch Johnston, director of the Center for Earthquake Research and Information at Memphis State University, said at the hearing that progress on a local statute enforcing tougher building standards had accelerated remarkably after the Loma Prieta earthquake, and that new laws could be in place by the end of this year. But those measures apply only to the city of Memphis and its local county, and contain no requirements for retrofitting of

Although these issues and others, such as the availability and cost of earthquake insurance, were seriously discussed, it is unlikely that any real initiatives will emerge from last week's hearing. As Don Ritter (Republican, Pennsylvania) put it, "the 1812 New Madrid earthquake is probably as far from the thoughts of the citizens of Memphis, Tennessee, as the 1812 overture is from the citizens of Nash-

David Lindley

\title{
Stanford in squabble over relief funds
}

\section{San Francisco}

STILl reeling from the physical damage, estimated at $\$ 160$ million, suffered in the Loma Prieta earthquake on 17 October, officials at Stanford University, $\mathbf{4 0}$ miles south of San Francisco, found themselves on the public relations defensive last week after a senator in the California legislature maligned them for a lobbying campaign to get state relief funds that, it was suggested, were better deserved by more needy groups.

The controversy started when Democratic state senator Bill Lockyer tried to limit to $\$ 1$ million the amount of state aid a private, non-profit institution such as Stanford could receive. But he quickly ran into opposition as the package wound its way through the layers of state government. First, the limit on funds was raised to $\$ 5$ million. Then, when the bill was finally signed into law earlier this month by Governor George Deukmejian (Republican), the limit was waived altogether unless relief funds ran out.

The final form of the law upset Lockyer, who directed his anger at Stanford University. "Stanford was the main lobbying force arguing against any cap at all", he claimed, adding that representatives of the university attended all the discussions: they were "in the common hearings, at the lobbying gate, visiting people's offices and buttonholing them for the whole week". The senator was incensed that the wealthy institution used its considerable legislative weight to try and push through its package, especially as it has a $\$ 1,800$-million endowment. "I'm not a Stanford basher", Lockyer said, "I think it's a wonderful institution, and their contributions to our culture are enormous." What irked him, he said, was that "a lot of other people or organizations that are less fortunate don't have similar capacities to take care of their own problems". For their part, Stanford officials were stunned by the accusations, and have written to the editors of both the campus paper and a local newspaper defending their actions. "I'm really surprised that this has somehow become newsworthy", said spokesman Larry Horton. He acknowledged that the cap was the subject of a major debate in the Senate, but said that the university was only supporting what it thought was the most reasonable position.

\section{Zacher is new president \\ Munich}

THE senate of the Max-Planck Society (MPS) last week selected Hans Zacher, now director of the Max-Planck Institute for foreign and international social law, as the organization's new president. Zacher, who was the only nominee presented to the senate, will begin a six-year term in mid1990. He is the first president to emerge

\section{IMAGE UNAVAILABLE FOR COPYRIGHT REASONS}

Zacher will take office in mid-1990.

from the humanities section of the MPS in its $\mathbf{4 1}$ years, and succeeds Heinz Staab, who returns after his six-year term to the MaxPlanck Institute for Medical Research in Heidelberg.

With 62 institutes and an annual budget of DM1,240 million ( $\$ 670$ million), MPS is the largest research organization outside the universities in West Germany. Only ten of the institutes are in the humanities, the rest covering biology and medicine, chemistry, physics and technology. Zacher, who is 61 and a pioneer of social law research for whom the institute for foreign and international social law was founded in 1980 , now faces problems familiar to the heads of all science organizations in West Germany: an expected wave of retirements among directors late in the next decade, accompanied by the need to find positions for a flood of young researchers. Some MPS members worry that the organization of the society is not flexible enough to handle all the changes (see Nature 340,$335 ; 1989$ ). 